\title{
Running Stabilization Control of Electric Vehicle Based on Cornering Stiffness Estimation
}

\author{
Akio Tsumasaka Member (Nagaoka University of Technology) \\ Hiroshi Fujimoto Member (Yokohama National University) \\ Toshihiko Noguchi Member (Nagaoka University of Technology)
}

Keywords: cornering stiffness, real-time estimation, yaw-moment observer, running stabilization control, anti-slip control, electric vehicle

In this paper, two control systems are proposed for electric vehicles (EVs) with in-wheel motors. In both methods, novel anti-slip control is utilized as an inner-loop system to control longitudinal motion of the vehicle. The stability robustness is theoretically guaranteed by modeling a road condition change as an inertia variation with dead time.

First, as an outer-loop lateral controller, a simple direct yawmoment control (DYC) is proposed based on a yaw-moment observer (YMO) as shown in Fig. 1. The observer can nominalize the yawing dynamics by compensating unknown nonlinear lateral force and disturbance yaw-moment as lumped disturbance.

Secondly, an advanced DYC is proposed with road condition estimation as shown in Fig. 2. In this system, an immeasurable parameter known as cornering stiffness is estimated from the detected yawrate, steering angle, wheel speed and yaw-moment observer output in real-time. Thus, the accurate control input can be generated with the estimated parameter.

These two methods are applied to a small EV with two in-wheel motors in rear wheels. The proposed adaptive control is compared with the robust control based on the YMO on dry and snowy terrain conditions. The experimental results show that the yaw-rate error is well attenuated by the proposed control systems, as shown in Figs. 3 and 4.

Small EVs are expected to be popular as new transportation system of urban and rural areas as a commuter car, a second car, a

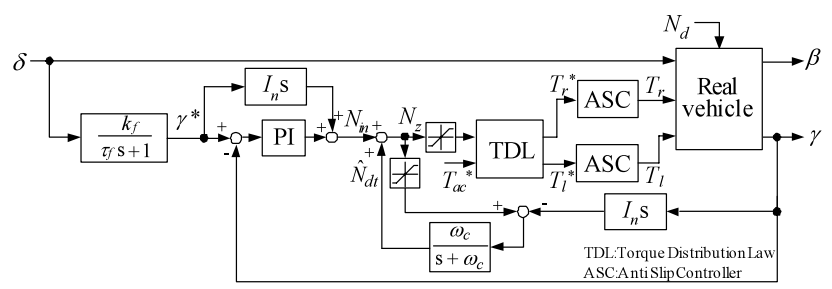

Fig. 1. Proposed system with yaw-moment observer

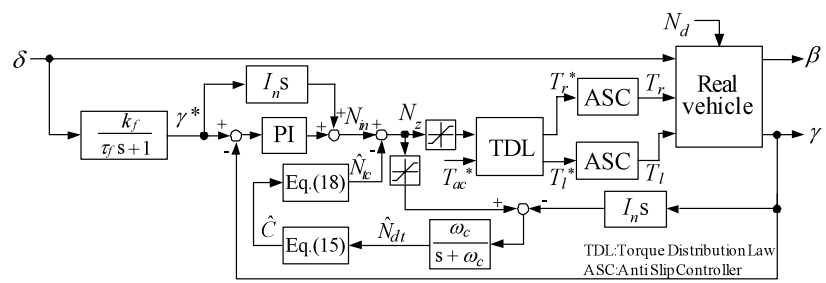

Fig. 2. Proposed system with cornering stiffness estimation delivery service car, or an elderly persons' vehicle. When these vehicles are driven in cold district, there are risks of skid, slip, drift, or spin on snowy or iced road. Thus, the proposed methods of braking/traction control and DYC are significantly important solutions for safer and human-friendly driving.

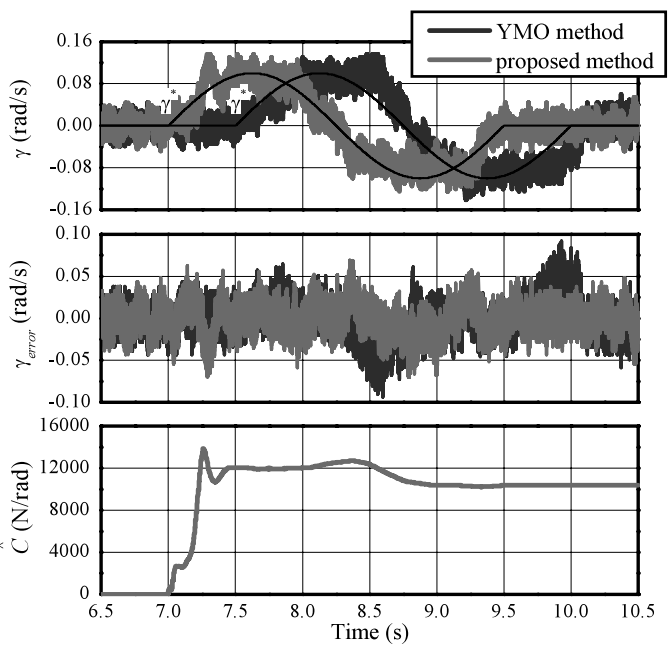

Fig. 3. Experimental results of stabilizing control on dry terrain

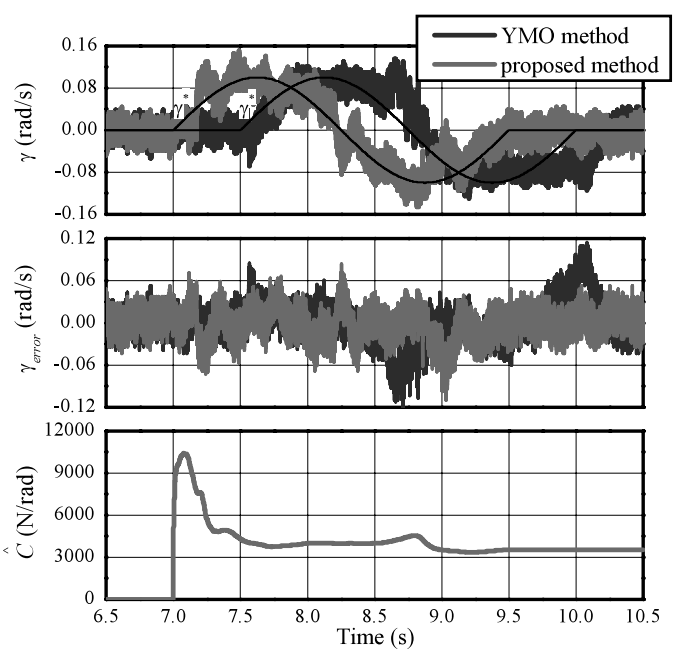

Fig. 4. Experimental results of stabilizing control on snow terrain 


\title{
コーナリングスティフネス推定值を用いた 電気自動車の走行安定化制御
}

\author{
正 員 裙坂 昭生* 正 員 藤本 博志** \\ 正 員 野口 季彦*
}

\section{Running Stabilization Control of Electric Vehicle Based on Cornering Stiffness Estimation}

Akio Tsumasaka*, Member, Hiroshi Fujimoto**, Member, Toshihiko Noguchi*, Member

In this paper, novel direct yaw-moment control (DYC) with road condition estimation and anti-slip control is proposed for electric vehicles. An inner-loop observer controls the vehicle traction, and an outer-loop observer stabilizes the yawing motion of the vehicle. An immeasurable parameter known as cornering stiffness is estimated from the detected yaw-rate, steering angle, wheel speed and yaw-moment observer output in real time. Thus, the accurate control input can be generated with the estimated parameters. The proposed adaptive control is compared with a conventional robust control method on dry and snowy terrain conditions. Experimental results show that the proposed control algorithm properly attenuates the yaw-rate error.

キーワード：コーナリングスティフネス，実時間推定法，ヨーモーメントオブザーバ，走行安定化制御，アンチスリップ制 御, 電気自動車

Keywords: cornering stiffness, real-time estimation, yaw-moment observer, running stabilization control, anti-slip control, electric vehicle

\section{1. はじめに}

電気自動車 (Electric Vehicle：EV) は, 内燃機関の排気 による地球温暖化問題や化石燃料の枯渇問題などに対して 非常に優れた点を有しているため，内燃機関自動車（Internal Combustion Engine Vehicle：ICEV) に代わって今後普 及すると期待されている。しかし，排気規制が厳しく定め られることにより，電子制御技術が進化して内燃機関の環 境負荷も年々改善されている。また，ハイブリッド自動車 (Hybrid Vehicle : HV) の開発によって然費性能も更に良 くなり，水素を燃料とする燃料電池車 (Fuel-Cell Hybrid Vehicle：FCHV) までも登場した ${ }^{(1)}$ 。

EV はモータで純電気的に駆動することから，モー夕駆 動の優位性である分散配置可能なことや高速なトルク応答 を活かして，高度な駆動力制御と走行安定化制御を同時に 期待することができる(2)(3)。また，この利点は純 EV だけで

\footnotetext{
*長岡技術科学大学

干 940-2188 長岡市上富岡町 1603-1

Nagaoka University of Technology

1603-1, Kamitomioka, Nagaoka 940-2188

** 横浜国立大学

干 240-8501 横浜市保土ケ谷区常盤台 79-5

Yokohama National University

79-5, Tokiwadai, Hodogaya, Yokohama 240-8501
}

はなく, HV や FCHV などモー夕を主駆動源とする広義の $\mathrm{EV}$ にも応用できる。

筆者らは外乱オブザーバを応用して，並進方向の制御を 司るインナーループのアンチスリップオブザーバを用いた 車輪速制御法と, 回転方向の制御を担うアウターループの ヨーモーメントオブザーバを用いた走行安定化制御法を提 案してきた。これらの制御法は, 測定や推定が困難な变数 や車両パラメータが不要なロバスト制御に基づくシンプル なアルゴリズムである ${ }^{(4)}$ 。また，ヨーモーメントオブザー バを応用したコーナリングスティフネス推定法も提案し, 推定実験により，その推定アルゴリズムや推定值の妥当性 を検証してきた ${ }^{(5)}$ 。推定困難な未知パラメータであるコー ナリングスティフネスを本手法により推定し, 車両モデル を用いてヨーモーメントを適応的に制御すれば，より正確 で高速な制御が可能となる ${ }^{(6)}$

本稿では後二輪にインホイールモータをもつ小型 EVを 用いて，提案法とヨーモーメントオブザーバを用いた従来 の制御法を比較検討し, 乾燥路面, 雪路面においてはマイ ナーな制御系にアンチスリップオブザーバを用いた車輪速 制御を施し二次元の走行安定化制御実験を行った。その結 果，提案する制御法の有効性を検証できたので報告する。 


\section{2. アンチスリップオブザーバによる車輪速制御}

〈2·1 並進方向運動方程式図 1 において, 完全粘 着を仮定したときの前後並進運動に関する運動方程式は次 式で表される。

$$
\left(J_{\omega}+m r^{2}\right) \frac{d \omega}{d t}=T
$$

ただし， $J_{\omega}$ は車輪回転部分慣性モーメント $\left(\mathrm{kgm}^{2}\right), m$ は 車両重量 $(\mathrm{kg}), r$ は夕イヤ半径 $(\mathrm{m}), T$ はモータトルク $(\mathrm{Nm}), \omega$ は駆動輪回転速度（rad/s）である。

(1) の括弧内第 2 項は，車軸換算の車体慣性モーメントで ある。車輪空転現象が起きるとこの第 2 項は大きく減少し, 見かけ上車両全体の慣性が小さくなったように振舞う ${ }^{(2)}$ 。 本論文ではこの現象を利用してアンチスリップ制御を行う。

$\langle\mathbf{2} \cdot \mathbf{2}\rangle$ 車輪速制御 提案する外乱オブザーバによる アンチスリップ制御系を図 2 に示す。図 2 はプラント $P(s)$ と外乱オブザーバを表し, 入力は上位制御系からのトルク 指令值の電流換算值 $I^{*}(\mathrm{~A})$, 外乱トルク $T_{d i s}(\mathrm{Nm})$, セン サノイズ $n(\mathrm{rad} / \mathrm{s})$ であり, 出力は駆動輪回転速度 $\omega$ となっ ている。 $K_{t}$ はモータトルク定数 $(\mathrm{Nm} / \mathrm{A}), K$ はオブザーバ ゲイン， $\tau_{i}$ はオブザーバの時定数 $(\mathrm{s})$ である。上述のよう に, 路面の変化を慣性変動と捉え, それを車両モデルの乗 法的誤差として考えると次式で表される。

$$
\frac{1}{J \mathrm{~s}}=\frac{1}{J_{n} \mathrm{~s}}(1+\Delta)
$$

$J_{n}$ は車輪と車体を合わせた回転部分の慣性を各駆動輪単位 に換算したノミナル值であり，タイヤが粘着状態にあると きの慣性モーメント $\left(\mathrm{kgm}^{2}\right)$ である。一方，Jはプラント の慣性モーメントであり，車輪粘着時は (1) の括弧内に相 当し，車輪空転時は $J_{\omega}$ またはそれに近い值になる。また，

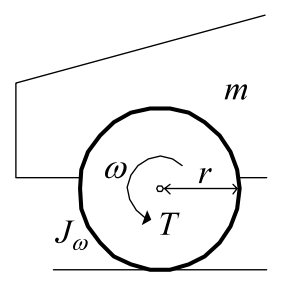

図 1 車輪一輪モデル

Fig. 1. One-wheel vehicle model.

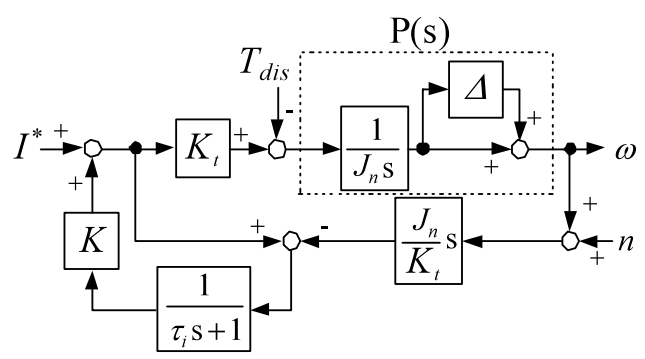

図 2 アンチスリップ制御ブロック線図

Fig. 2. Block diagram of anti-slip control.
、はプラントの変動である。ここで, 実験システムにはサ ンプリングに起因する遅れやエンコーダの分解能に起因す る速度検出遅れ, さらにはモータがトルクを出してから夕 イヤの動特性を介して実際に駆動力が発生するまでにも遅 れが存在すると考えられる。そこで不確かさ $\Delta$ にむだ時間 $T_{d}$ (s) を考慮すると (2) は,

$$
P(s)=\frac{1}{J_{\mathrm{S}}} e^{-s T_{d}}=\frac{1}{J_{n} \mathrm{~s}}(1+\Delta(s))
$$

となり，これより $\Delta$ について再記述すると，

$$
\Delta(s)=\frac{J_{n}}{J} e^{-s T_{d}}-1
$$

と表される。このむだ時間を含んだプラントを出力端にゲ イン $K$ をもつ外乱オブザーバによりノミナル化し, アンチ スリップ制御を実現する ${ }^{(4)}$ 。

3. ヨーモーメントオブザーバを用いた走行安定化 制御 (4) (従来法)

〈3・1〉車両運動方程式車両モデルとして図 3 に示 したように四輪を車軸に関して対称と仮定した二輪車モデ ルを想定し, 車体のローリングはなく一定速度で走行して いると仮定する。この車両モデルの水平面内における運動 方程式は次式で表される ${ }^{(7)}$ 。

$$
\begin{aligned}
& m V\left(\frac{d \beta}{d t}+\gamma\right)=2 Y_{f}+2 Y_{r} \\
& I \frac{d \gamma}{d t}=2 Y_{f} l_{f}-2 Y_{r} l_{r} \ldots .
\end{aligned}
$$

ただし， $m$ は車両重量 $(\mathrm{kg}), V$ は車両速度 $(\mathrm{m} / \mathrm{s}), \beta$ はす ベり角 $(\mathrm{rad}), \gamma$ はヨーレート $(\mathrm{rad} / \mathrm{s}), I$ はヨー軸回りの車 両慣性 $\left(\mathrm{kgm}^{2}\right), l_{f}, l_{r}$ はそれぞれ車両重心から前輪軸, 後 輪軸までの距離 $(\mathrm{m})$ である。 $Y_{f}, Y_{r}$ は前輪, 後輪のコー ナリングフォース（N) であり，夕イヤの特性に依存する 非線形変数である。

$\langle\mathbf{3 \cdot 2}\rangle$ 走行安定化制御法 上記の $\beta$ と $V$ を測定する

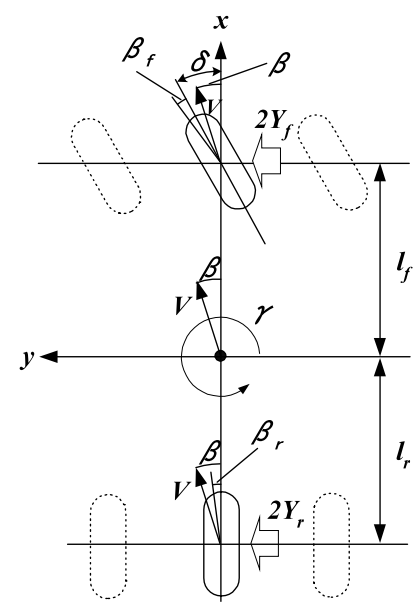

図 3 等価二輪車モデル

Fig. 3. Equivalent two-wheel vehicle model. 


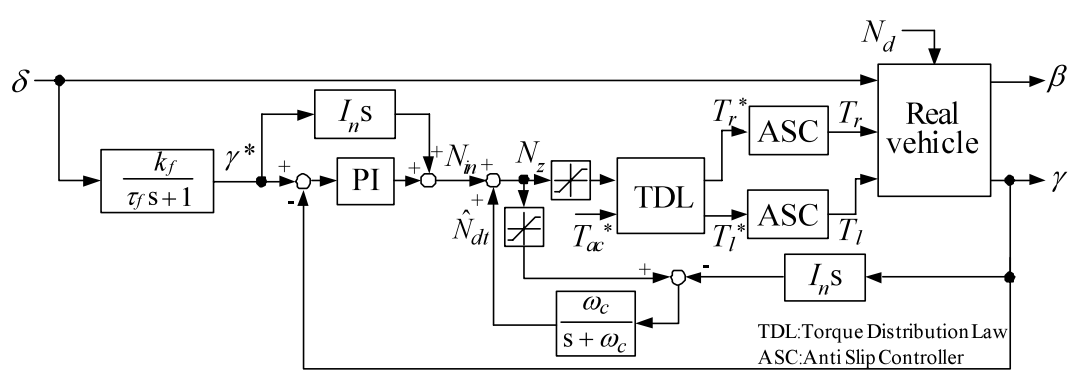

図 4 ヨーモーメントオブザーバを用いた走行安定化制御ブロック線図

Fig. 4. Block diagram of vehicle stability control based on yaw-moment observer.

には車両の実速度べクトルが必要となる。また，コーナリン グフォースについては非線形変数であるので測定や推定は 困難である。そこで，これらの変数による影響を外乱モーメ ントと捉え，外乱オブザーバによる一括補償法を検討する。 (6) の右辺で表されるタイヤに発生するコーナリングフ オースによるモーメントを $N_{t}$ とし，(6) で考慮されていな い路面状況の変化，横風などによる外乱モーメントを $N_{d}$,

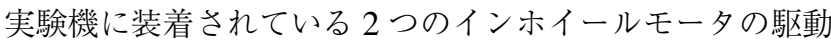
力差により生成できるヨー軸回りのモーメントを $N_{z}$ とし, $N_{d t}=N_{d}-N_{t}$ とおくと，(6)は，

$$
I \frac{d \gamma}{d t}=N_{z}-N_{d t}
$$

と簡単化される。(7)において，ヨーレート $\gamma$ を検出し， 図 4 に示されるヨーモーメントオブザーバを構成すれば外 乱モーメントは抑圧され， $\omega_{c}$ 以下の帯域では，

$$
\gamma=\frac{1}{I_{n} s} N_{\text {in }}
$$

とノミナル化される。ただし，最もマイナーな制御系には 先に述ベたアンチスリップオブザーバを用いた駆動輪の粘 着制御を施し，任意の駆動力モーメントを確実に発生でき るものとする。

本システムでは生成した駆動力モーメント $N_{z}$ を以下の 方法で左右の車輪に駆動力分配する (2)。

$$
\begin{aligned}
& N_{z}=l_{p}\left(F_{r}^{*}-F_{l}^{*}\right) \\
& T_{a c}^{*}=F_{r}^{*}+F_{l}^{*} \cdots
\end{aligned}
$$

ただし， $T_{a c}^{*}$ はアクセル指令值 $(\mathrm{Nm}), F_{r}^{*}, F_{l}^{*}$ は右輪, 左輪 の駆動力指令值 $(\mathrm{Nm})$ である。(9), (10) を解くことで, 左 右それぞれの車輪駆動力を決定することができる。さらに，

$$
T_{r}^{*}=r F_{r}^{*}, \quad T_{l}^{*}=r F_{l}^{*}
$$

として, 各車輪駆動モー夕に対するトルク指令值を決定す

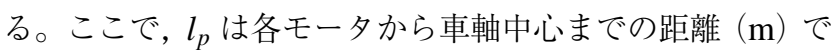
ある。

なお，本システムに扔いて，ヨーレート指令值 $\gamma^{*}$ を生成 するためには，図 4 のブロック線図に示すような舵角 $\delta$ か ら $\gamma^{*}$ に至る一次遅れの伝達要素をフィードフォワードモデ ルとして設けている。

$$
G_{\gamma \delta}(s)=\frac{k_{f}}{\tau_{f} s+1}
$$

\section{4. コーナリングスティフネス推定值を用いた走行 安定化制御（提案法）}

〈4・1〉推定アルゴリズム（6)に扔いて，前輪，後輪 のコーナリングフォース $Y_{f}, Y_{r}$ は次のように表される(7)。

$$
Y_{f}=-C_{f}\left(\beta+\frac{l_{f}}{V} \gamma-\delta\right), \quad Y_{r}=-C_{r}\left(\beta-\frac{l_{r}}{V} \gamma\right)
$$

$C_{f}, C_{r}$ は前輪, 後輪のコーナリングスティフネス $(\mathrm{N} / \mathrm{rad})$ である。(6)に挄て，モデルを簡単化するため重心から前 輪軸, 後輪軸までの距離を $l_{f}=l_{r}=l$, 前輪, 後輪のコーナ リングスティフネスを $C_{f}=C_{r}=C$ とすれば，(7)は，

$$
I \frac{d \gamma}{d t}=N_{z}+C\left(-\frac{4 l^{2}}{V} \gamma+2 l \delta\right)-N_{d}
$$

となる。(14)の右辺括弧内を $と$ とれば，図 5 のヨーモー メントオブザーバ出力から，

$$
\hat{N}_{d t}=-C \zeta+e \text {. }
$$

と表すことができる。 $e=N_{d}-\tilde{N}_{d t}$ が十分小さいかホワイ トであれば最小二乗法によりコーナリングスティフネス $C$ の推定が可能となる。ただし, $\tilde{N}_{d t}$ はオブザーバの推定誤 差 $N_{d t}-\hat{N}_{d t}$ である。

(14)，(15) からわかるように検出が困難なすべり角 $\beta$ に 依存せず，ヨーモーメントオブザーバ出力と直接検出でき

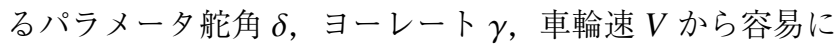
$C$ を推定することができる。

コーナリングスティフネスの推定には重みつき逐次形最 小二乗法を採用し, その推定式を(16)に, 適応ゲインの更 新式を(17) に示す ${ }^{(8)}$ 。入は忘却係数であり, 後述するよう に条件付きアップデートアルゴリズムを用いている。

$$
\begin{aligned}
\hat{C}(k)= & \hat{C}(k-1) \\
& -\frac{\Gamma(k-1) \zeta(k)}{\lambda+\zeta^{2}(k) \Gamma(k-1)}\left[\zeta(k) \hat{C}(k-1)+\hat{N}_{d t}(k)\right] \\
\ldots \ldots \ldots \ldots \ldots \ldots & (16) \\
\Gamma(k)= & \frac{1}{\lambda}\left[\Gamma(k-1)-\frac{\Gamma^{2}(k-1) \zeta^{2}(k)}{\lambda+\zeta^{2}(k) \Gamma(k-1)}\right] \ldots \ldots .(17)
\end{aligned}
$$




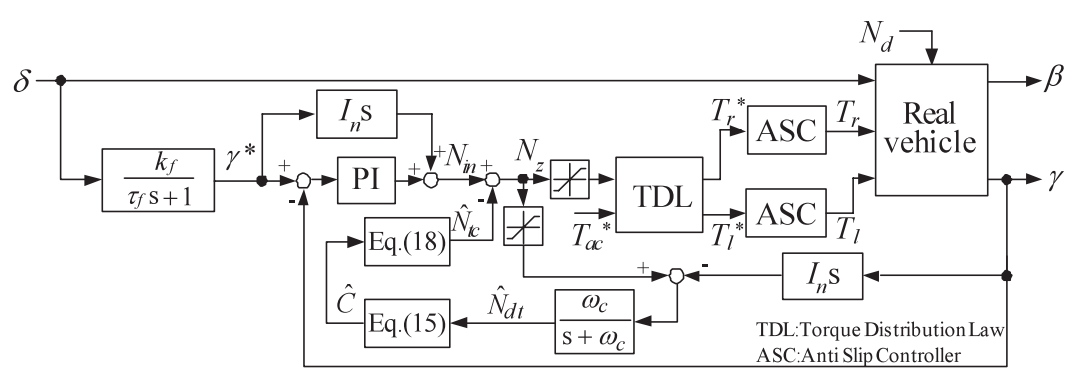

図 5 コーナリングスティフネス推定值を用いた走行安定化制御ブロック線図

Fig. 5. Block diagram of vehicle stability control based on cornering stiffness estimation.

〈4·2〉 走行安定化制御法 推定した $\hat{C}$ ，すべて測定 可能な変数とパラメータからなるらから, タイヤに発生す るコーナリングフォースによるモーメント推定值は,

$$
\hat{N}_{t c}=\hat{C} \zeta
$$

となるため，すべて既知の值から推定することができる。

(7) について, ヨーレートを検出し, 図 5 に示すシステム を構成すれば, 推定值 $\hat{C} に よ り$ 生成された $\hat{N}_{t c}$ により系が ノミナル化され， $\hat{C} \cong C$ のと，

$$
\gamma=\frac{1}{I_{n} s} N_{\text {in }}
$$

となる。ただし，上式において $N_{d}=0$ としている。また， 最もマイナーな制御系には先に述べたアンチスリップオブ ザーバを用いた車輪速制御を施し，任意の駆動力モーメン トを発生できるものとする。駆動力の分配やヨーレート指 令值 $\gamma^{*}$ の生成については, ヨーモーメントオブザーバを用 いた走行安定化制御と同様である。

\section{5. 車両制御のシミュレーション結果}

図 4, 図 5 のように構成された両制御システムにおいて, (12) を用いず $\gamma^{*}$ に振幅 $0.1(\mathrm{rad} / \mathrm{s})$, 周波数 $0.4(\mathrm{~Hz})$ の正 弦波を直接与え， $\gamma^{*}$ に対する $\gamma$ の目標值応答特性をシミュ レーションにより検証した。提案法は $7.0(\mathrm{~s})$, 従来法は 7.5 (s) から $\gamma^{*}$ をえている。シミュレーション条件は, $\delta=0$ $(\mathrm{rad}), m=400(\mathrm{~kg}), V=20(\mathrm{~km} / \mathrm{h}), I=160\left(\mathrm{kgm}^{2}\right)$, $l_{f}=0.689(\mathrm{~m}), l_{r}=0.591(\mathrm{~m}), \quad l=\left(l_{f}+l_{r}\right) / 2=0.64$ $(\mathrm{m}), C=C_{f}=C_{r}=10000(\mathrm{~N} / \mathrm{rad})$, PI ゲイン $k_{p}=100$ $\left(\mathrm{kgm}^{2} / \mathrm{s}\right), k_{i}=30000\left(\mathrm{kgm}^{2} / \mathrm{s}^{2}\right), \lambda=0.9999$, 入力外乱 $N_{d}=0(\mathrm{Nm})$ としている。ヨーモーメントオブザーバのカッ トオフ周波数 $\omega_{c}$ は実際の実験システムを想定して $\omega_{c}=5.0$ $(\mathrm{rad} / \mathrm{s})$ と設定した。また，ヨーレートの制御入力である $N_{z}$ には実機システムを想定してリミッタ $\pm 367(\mathrm{Nm})$ も設け ている。

シミュレーション結果を図 6 に示す。提案法を用いるこ とにより， $\gamma$ が $\gamma^{*}$ に遅れることなく良好に追従することか ら誤差 $\gamma_{\text {error }}$ を小さく抑えられていることがわかる。これ は, 提案法のオブザーバ出力である $\hat{N}_{t c}$ がより忠実に路面 発生力を再現することで, 必要なモーメント制御入力 $N_{z}$ が 正確に生成されるからである。

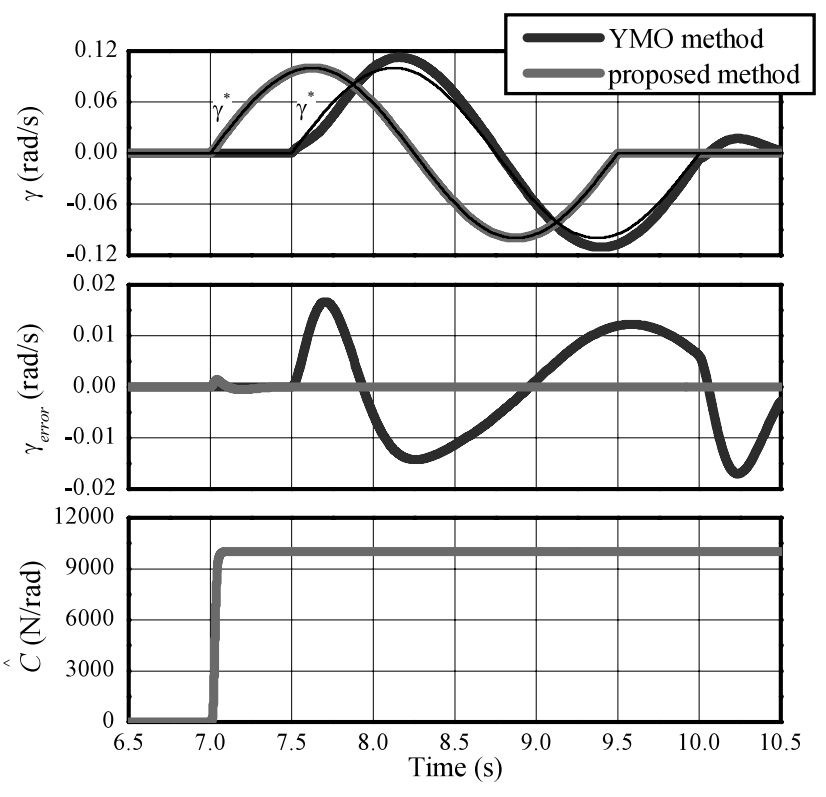

図 6 目標值応答シミュレーション結果

Fig. 6. Simulation result of command response.

\section{6. 車両制御の実験結果}

〈6・1〉 実験システム 実験システムの構成を図 7 に 示す。ホストコンピュータとして RT-Linux を搭載したデ スクトップ PC を用い, モータコントローラとして SH マ イコンを用いている。各種センサ信号は PCI バスを介し て A/D ボードから入力する。ホストコンピュータでは左右 モータに対するトルク指令值が計算され，このトルク指令 值は光ファイバーを介してシリアル通信により SH マイコ ンに送られる。SH マイコン内ではモータの電流制御が行 われ，その電圧指令值に基づいて生成されたパルス幅変調 (PWM) 信号がインバータに入力される。車輪速検出につ

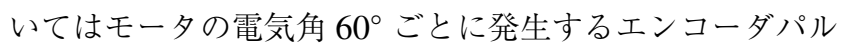
スを利用し，SH マイコンでこのパルス間隔を計測して計測 值をホストコンピュータに送信することにより車輪速を求 める。モー夕の電流制御は左右独立に 2 個の SH マイコン で行っており, ホストコンピュータからのトルク指令值に 応じて電流制御を行う。始動時はエンコーダ情報を用いる ことが困難なので 6 ステップ通電方式としているが，基本 


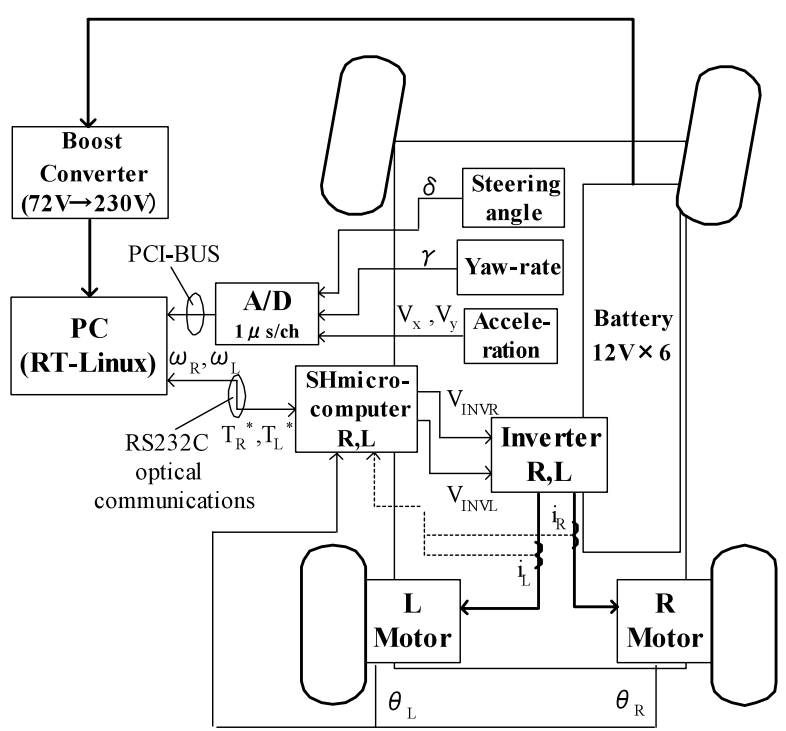

図 7 実験システムの構成

Fig. 7. Configuration of experimental setup.

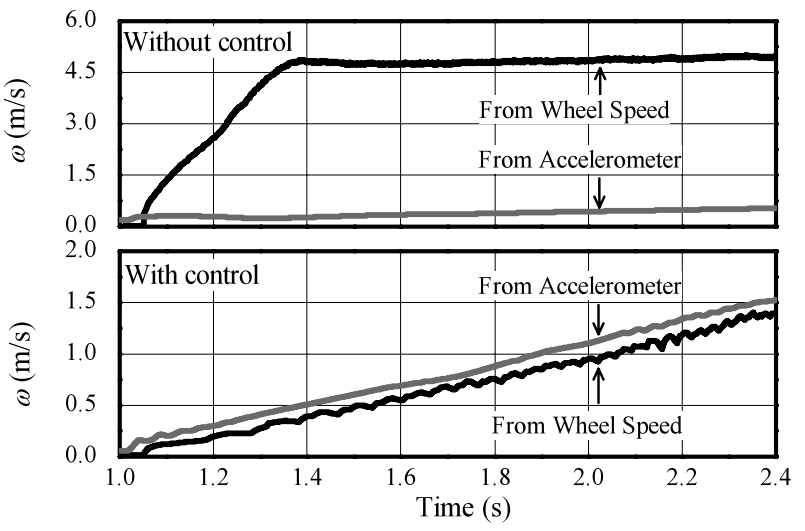

困 8 アンチスリップ制御実験結果

Fig. 8. Experimental results of anti-slip control.

波周波数が $30(\mathrm{~Hz})$ を超えるとエンコーダ情報を用いて正 弦波電流制御に基づくベクトル制御方式に切り換えている。 ベクトル制御駆動時の連続した位相はエンコーダのパルス 間隔を外挿することにより計算している。また，基本波周 波数が $35(\mathrm{~Hz})$ を超えると弱め界磁制御を行っている(9)。

〈6・2〉 アンチスリップ制御実験＼cjkstart実験はシャーベッ 卜状の雪路面で行った。電流指令值（トルク指令值）はス テップ入力とし，1（s）から50（A）与えている。各パラ メータである $J_{n} / K_{t}$, オブザーバカットオフ，ゲインはそれ ぞれ $J_{n} / K_{t}=7\left(\mathrm{As}^{2}\right), \omega_{i}=30(\mathrm{rad} / \mathrm{s}), K=0.7$ とした ${ }^{(4)}$ 。

図 8 の実験結果は車輪速度と加速度センサの信号を 100 $(\mu \mathrm{s})$ でデジタル積分した車体速度を示している。加速度セ ンサ信号を積分した車体速度にオフセットが見られるのは センサノイズが重畳したためである。しかし，ノイズはデ ジタル積分することにより平均化され，車体速度の勾配自 体には問題がない。非制御時は大空転が発生し車輪速度が 大きく跳ね上がっているが，本制御法を適用することによ
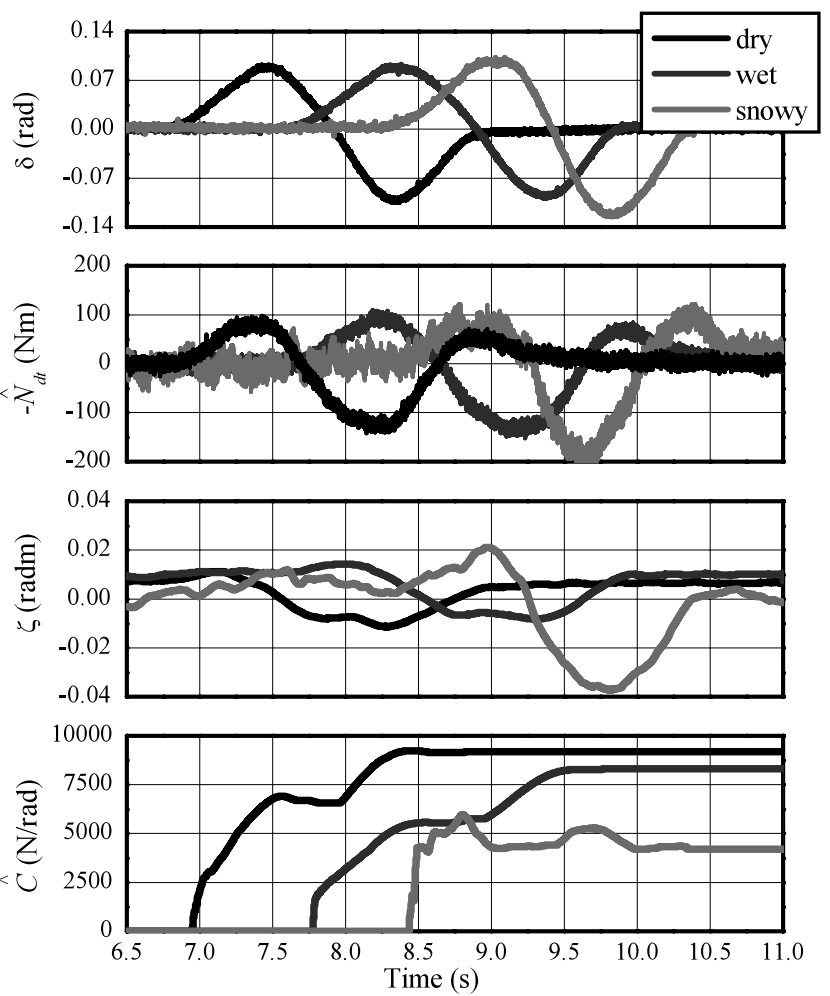

図 9 各路面に扮ける推定実験結果

Fig. 9. Estimation result of experiment on snowy terrain.

り良好な車輪速度の応答を確認できる。また，本制御法を 適用することにより車輪速度とセンサ值の示す車体速度が 同じ勾配で増加している。この結果からスリップが発生せ ず，タイヤと路面の間の摩擦力を維持しながら加速してい ることがわかる。

〈6·3 コーナリングスティフネス推定実験＼cjkstart実験は 乾燥路面, 濡れた路面, シャーベット状の雪路面の 3 条件 で行い，いずれの条件でも $20(\mathrm{~km} / \mathrm{h})$ で走行中に舵角 $\delta$ を 正弦波状に入力している。このとき，ヨーレートの制御系 を動作させていないので, 制御入力 $N_{z}$ は 0 とした。ヨー モーメントオブザーバのカットオフ周波数は $5.0(\mathrm{rad} / \mathrm{s})$ と し，車両慣性のノミナル值 $I_{n}$ は $160\left(\mathrm{kgm}^{2}\right)$ としている。 推定のアップデート条件として (15) の出力である $\hat{N}_{d t}$ に 闇值 $25(\mathrm{Nm})$ を設け，閾值以下の推定に有効な信号が来な くなると推定值を更新せずそれまでの值を保持するように

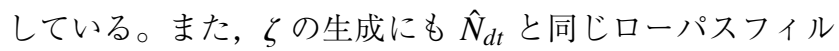
夕を用いている。全ての実験でのサンプリング時間 $T_{s}(\mathrm{~s})$ は200 $(\mu \mathrm{s})$ としている。雪路面での推定時の忘却係数は ノイズの影響と収束性を考慮して $\lambda=0.9999$ とし, 最もマ イナーな制御系にはアンチスリップオブザーバを用いた車 輪速制御を施している。

図 9 に推定実験結果を示す。実験結果から乾燥路面では $9200(\mathrm{~N} / \mathrm{rad})$, 濡れた路面では $8300(\mathrm{~N} / \mathrm{rad})$, 雪路面では $4300(\mathrm{~N} / \mathrm{rad})$ という異なった推定值が得られた。得られ た推定值の妥当性を確認するために，実験で測定したヨー レート $\gamma$ が推定值から再現できるかを検証した。検証方法 


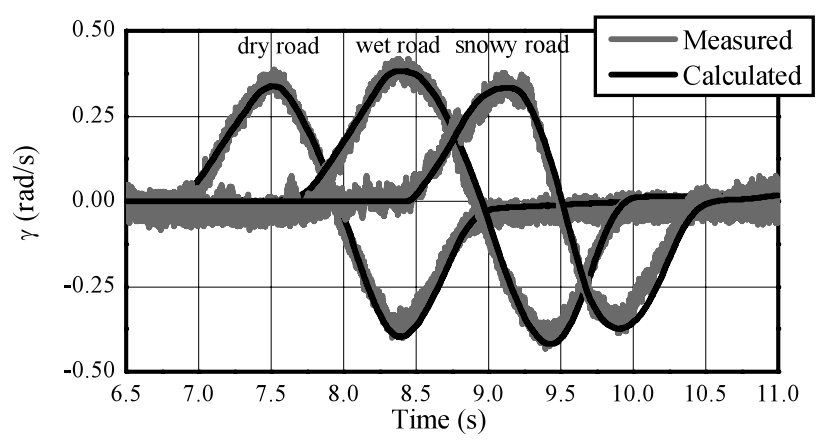

図 10 オフラインでのヨーレート再現計算結果

Fig. 10. Offline calculation results of yaw-rate.

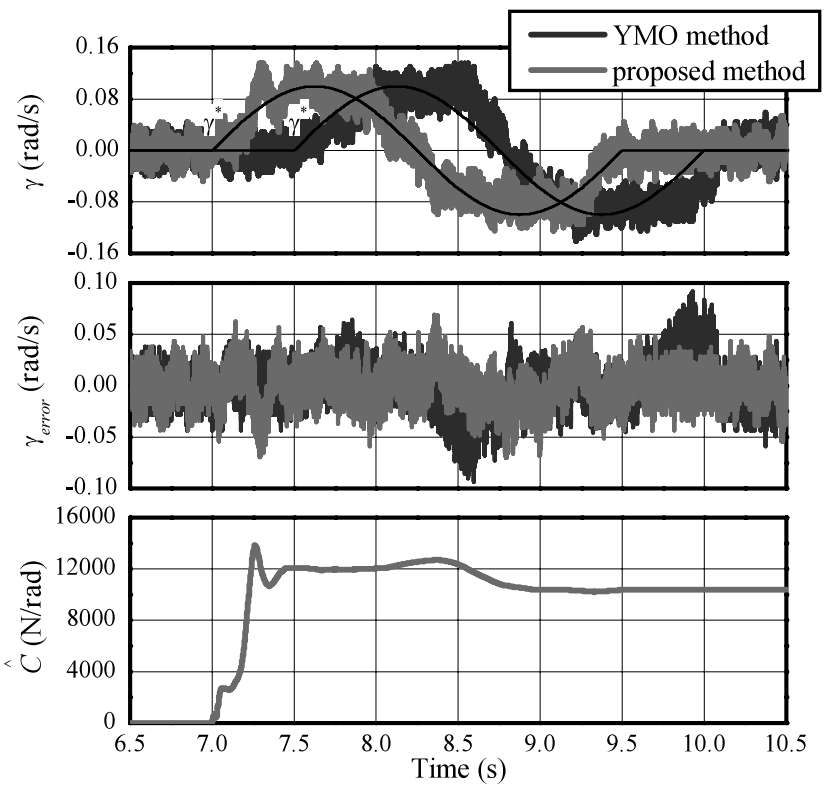

図 11 乾燥路面における走行安定化制御実験結果

Fig. 11. Experimental results of vehicle stabilizing control on dry terrain.

としては, 測定データの系列 $\delta, V$ と前節で得られた推定 值 $\hat{C}$ を(14) に代入して $\gamma$ をオフライン計算し, 実際に測 定された $\gamma$ との比較を行った。

図 10 にそれぞれの路面での再現計算結果を示す。路面状 況に関係なく良好に $\gamma$ を再現できていることがわかる。こ れらの結果から，滑りやすい路面ではコーナリングスティ フネスが小さくなることが数值的に立証でき，オフライン での $\gamma$ 再現計算結果も良好なことから路面状況を反映した 推定值の妥当性を確認できる。

〈6・4 走行安定化制御実験実験は乾燥路面と降雪 後の雪路面で行い，両制御法に押いて $20(\mathrm{~km} / \mathrm{h})$ で走行中 にヨーレート指令值 $\gamma^{*}$ を振幅 $0.1(\mathrm{rad} / \mathrm{s})$, 周波数 $0.4(\mathrm{~Hz})$ の正弦波で与えて， $\gamma^{*}$ に対するヨーレート $\gamma$ の目標值応答 特性を確認した。ステアリングを固定し舵角 $\delta=0(\mathrm{rad})$ で 提案法は $7.0(\mathrm{~s})$, 従来法は $7.5(\mathrm{~s})$ から $\gamma^{*}$ を与えている。

両制御法のヨーモーメントオブザーバのカットオフ周波数 は $5.0(\mathrm{rad} / \mathrm{s})$ とし, 車両慣性のノミナル值 $I_{n}$ は $160\left(\mathrm{kgm}^{2}\right)$

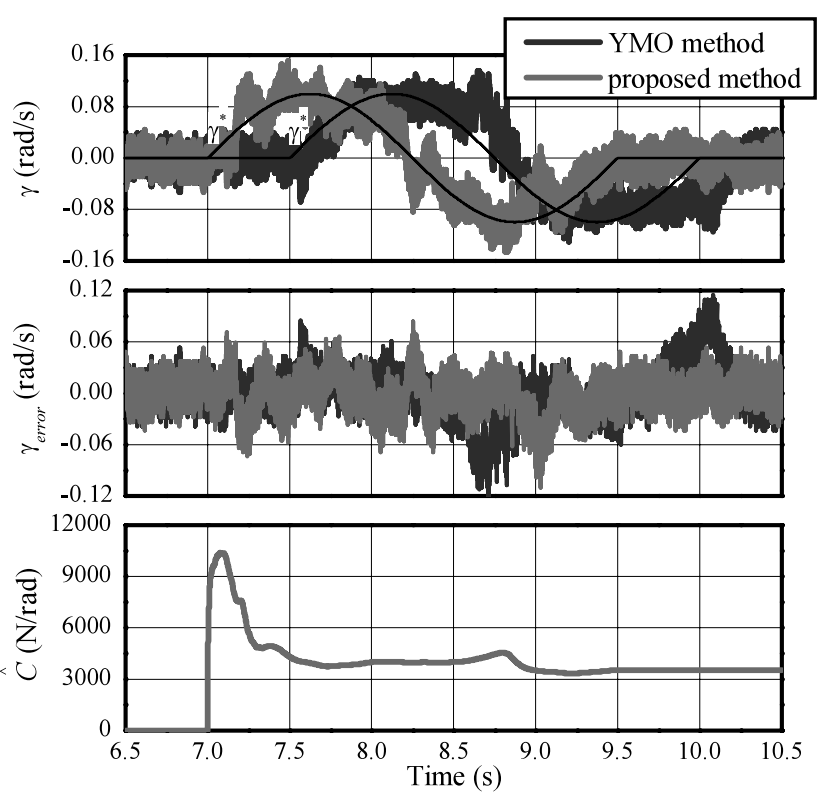

図 12 雪路面における走行安定化制御実験結果

Fig. 12. Experimental results of vehicle stabilizing control on snowy terrain.

としている。PI ゲインを $k_{p}=100\left(\mathrm{kgm}^{2} / \mathrm{s}\right), k_{i}=30000$ $\left(\mathrm{kgm}^{2} / \mathrm{s}^{2}\right)$, 制御入力 $N_{z}$ リミッタを $\pm 367(\mathrm{Nm})$ とするな ど，種々のパラメータは両制御法ともすべて同じ設定とし た。実験でのアクセル指令值 $T_{a c}^{*}$ は両制御法ともに同じと し, コーナリングスティフネス推定時のアップデート条件 などに関しては前節と同様である。雪路面での実験では, 最もマイナーな制御系にアンチスリップオブザーバを用い た車輪速制御を施している。

図11, 図 12 にそれぞれ乾燥路面, 雪路面での実験結果を 示す。両路面に打ける実験結果から, 提案法を用いること により $\gamma$ が $\gamma^{*} に$ に遅れずに良好に追従し誤差 $\gamma_{\text {error }}$ を小さく 抑制していることがわかる。また，コーナリングスティフ 交久推定值 $\hat{C}$ は乾燥路面で $10400(\mathrm{~N} / \mathrm{rad})$, 雪路面で 3700 $(\mathrm{N} / \mathrm{rad})$ という值が得られ，これらも妥当な結果であると 考えられる。

\section{7. まとめ}

本稿では，ヨーモーメントオブザーバを応用し全て既知 のパラメータからコーナリングスティフネスを推定する手 法と，その推定值を用いて車両モデルに基づき適応的に走 行安定化を図る制御法について述べた。

本推定法を用いることで路面状況を反映したコーナリン グスティフネス推定值が得られることを示し，ヨーレート 再現計算結果から得られた推定值の妥当性を確認した。ま た，ヨーモーメントオブザーバを用いた従来法と走行安定 化制御実験で比較評価した結果，提案法を用いることで各 路面状況に応じた走行が可能となり, 従来法よりも車両の 走行安定性が改善されることを示した。

(平成 17 年 3 月 16 日受付，平成 17 年 11 月 14 日再受付) 


\section{文献}

（1） GP 企画センター：最新エンジン・ハイブリッド・燃料電池の動向, グランプリ出版 (2003)

(2) S. Sakai, H. Sado, and Y. Hori: "Motion Control in Electric Vehicle with Four Independently Driven In-Wheel Motors", IEEE Trans. on Mech., Vol.4, No.1 pp.9-16 (1999-1)

(3) Y. Hori: "Future vehicle driven by electricity and Control-research on fourwheel-motored "UOT electric march II"", IEEE Trans. IE, Vol.51, No.5 pp.954-962 (2004-5)

(4) T. Saitou, H. Fujimoto, and T. Noguchi: "Traction and Steering Stabilization Control for Electric Vehicle Based on Slip and Yaw-Moment Observers", IEEJ Ind. Instrumentation and Control Tech. Meet., IIC-03-53, pp.41-46 (2003) (in Japanese)

齋藤健生・藤本博志・野口季彦：「スリップ及びヨーモーメントオブ ザーバを用いた電気自動車の操縦安定化制御法」, 電気学会産業計測 制御研資, IIC-03-53, pp.41-46 (2003)

(5) A. Tsumasaka, H. Fujimoto, and T. Noguchi: "Cornering Stiffness Estimation of Electric Vehicle Based on Yaw-Moment Observer", IEEJ Ind. Appl. Soc. Annual Conf., Vol.2, 2-51, pp.551-552 (2003) (in Japanese) 裙坂昭生・藤本博志・野口季彦：「ヨーモーメントオブザーバを用い た電気自動車のコーナリングスティフネス推定」,電気学会産業応用 部門大, Vol.2, 2-51, pp.551-552 (2003)

(6) A. Tsumasaka, H. Fujimoto, and T. Noguchi: "Yaw-Moment Stabilization Control of Electric Vehicle Based on Cornering Stiffness Estimation", IEEJ National Convention Record, Vol.4, 4-191, pp.308-309 (2004-3) (in Japanese)

裙坂昭生・藤本博志・野口季彦：「コーナリングスティフネス推定 值を用いた電気自動車のヨーモーメント安定化制御法」, 電学全大, Vol.4, 4-191, pp.308-309 (2004)

（7）安部正人：自動車の運動と制御 [第二版], 山海堂 (2003)

（8）堀 洋一 ·大西公平：応用制御工学, 丸善 (1998)

（9）武田洋次 · 松井信行 · 森本茂雄 - 本田幸夫：埋达磁石同期モー夕の 設計と制御, オーム社 (2001)
裙 坂 昭 生 (正員) 1980 年 8 月 11 日生。 2003 年 3 月長岡

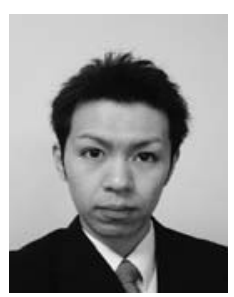
技術科学大学電子機器工学課程卒業。2005 年 3 月同大学院修士課程修了。2005 年 4 月本田技研 工業 (株) 入社。 2005 年 8 月ホンダエンジニア リング (株) に配属，現在に至る。

藤 本 博 志 (正員) 1974 年 2 月 3 日生。1 1996 年 3 月横浜国

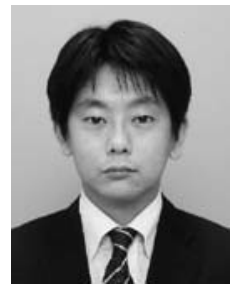
立大学工学部電子情報工学科卒業。1998 年 3 月 同大学大学院工学研究科電子情報工学専攻博士課 程前期 (修士課程) 修了。2001 年 3 月東京大学大 学院工学系研究科電気工学専攻博士課程修了。博 士 (工学)。同年 4 月長岡技術科学大学工学部電 気系助手。2002 年 8 月より 1 年間, 米国 Purdue 大学工学部機械工学科客員研究員。2004 年 4 月 横浜国立大学大学院工学研究院講師。2005 年 4 月同助教授。制御工 学, モーションコントロール, マルチレート制御に関する研究に従事。 2001 年 IEEE Trans. IE 最優秀論文賞など受賞。計測自動制御学会, 日 本ロボット学会, IEEE 各会員。

野口季 彦 (正員) 1959 年 10 月 23 日生。1982 年 3 月名古

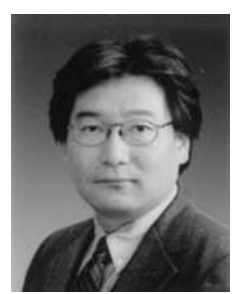
屋工業大学工学部電気工学科卒業。1986 年 3 月長 岡技術科学大学大学院工学研究科修士課程電気. 電子システム工学専攻修了。博士 (工学)。1982 年 4 月東京芝浦電気（株）入社。1991 年 4 月岐 阜工業高等専門学校講師。1 1994 年 4 月長岡技術 科学大学助手。1996 年 4 月同助教授。現在に至 る。IEEE 上級会員。 